(This is a version of the published essay prior to copy-editing and final revisions)

\title{
Rachid Taha and the Postcolonial Presence in French Popular Music
}

\author{
Jon Stratton
}

This essay considers the work of Rachid Taha from a postcolonial perspective. Taha is the most well-known French-Algerian musician working in popular music in France and now has a considerable following in the Anglophone world. There has been little sustained academic writing about Taha with the important exception of an article by Christa Jones in which she argues that: 'Rachid Taha est un muscien foncièrement cosmopolite, urbain et à la fois complètement déterritoralisé' [Rachid Taha is a fundamentally cosmopolitan musician, urban and yet completely deterritorialised] (original emphasis) (2009: 112). ${ }^{1}$ In this essay I am most concerned with the ways Taha's music expresses the experience of being identified as neither French nor Algerian while also feeling that both heritages are central to his identity as a Beur. I focus specifically on an understanding of Taha's work in terms of métissage, hybridity. Starting from a track on Carte de Séjour's first album, 'Rhorhomanie', which uses phrases from Arabic, French and English, I go on to examine examples of recordings where Taha has offered a revisioning of already well-known songs: Carte de Séjour's version of Charles Trenet's 'Douce France' [Sweet France], Taha's version of Dahmane el Harrachi's 'Ya Rayah', and, finally, Taha's version of the Clash's 'Rock The Casbah'.

\section{Becoming Beur}

The term 'Beur' is used to refer to second generation Algerians, or North Africans more generally, living in France. 'Beur' is verlan, the French slang which reverses the syllables of words, or, if a word is a single syllable, then reverses the sound of that word. In this case 'Beur' is the phonetic reversal of 'Arab'. Second generation here describes the children of those North Africans, mostly Algerians, who moved to France during the Trente Glorieuses, the thirty glorious years, from 1945 to 1975, of post-Second World War economic recovery and expansion. The majority of Beurs were born in France. Some, like Rachid Taha, were brought by their parents from Algeria at an early age. As we shall see, the relationship between France 
and its ex-colonies, and between those who see themselves as historically French and those whose origins are in the countries colonized by the French, is founded on a structure of extreme Otherness. Within this order, the French relationship with Algeria, and with the postcolonial presence of Algerians in France, has a particular complexity not least because between 1848 and 1962, when the Algerians won the eight-year War of Independence, Algeria was incorporated into France rather than being governed as a colony.

Algeria was invaded by the French in 1830. That part which was already conquered became a part of France in 1848 after the instauration of the Second Republic. However, during the time that Algeria was included in France, the Algerians were not granted citizenship. Rather, they remained subjects of the republic, unable to vote, but forced to pay taxes and ruled by the Code de l'indigénat [Code for the Indigenous People] which evolved between 1865 and 1881. Algeria highlighted the question central to Enlightenment philosophy and exposed in the debates that followed the Declaration of the Rights of Man:

To some, the French 'nation' was a bounded entity. Citizenship applied to people within its borders, and the plantation colonies of the Caribbean were its dependencies not constituent parts of the polity. Slaves could not be citizens. To others, colonial conquest and slavery were violations of the principles of Enlightenment, whether at home or overseas.

(Cooper 2009: 83)

At bottom the question for the French was, who is a 'man'; and, following from this, to whom should the rights associated with being a 'man' be given. As Frederick Cooper puts it:

Both the insistence on a singular, unitary vision of French republicanism and the exposé of the continued colonial nature of French society rely on two different readings of the last two hundred years of French history. One points to a continuing republican tradition emerging from the French revolution. The other sees a French nation exploiting 'others', from the slaves taken from Africa to the colonies of the West Indies to Africans exploited on their own territory. These two readings are mirror images of one another; they posit a very French France exploiting a very African Africa. 
The problem of the distinction between colonizer and colonized was based on a philosophical question that was deeply rooted in the foundations of post-revolutionary French society: are there limits, and if so what are they, to the category of 'man'? Discursively, as Cooper indicates, this question produced a profound division between 'French' and 'Other'. One effect of this way of thinking has been to suppress any discussion, or use, of race as a categorising machine. Erik Bleich writes that:

Even using the word 'race' in France often makes people shudder. This effect has carried over into the world of scientific inquiry and has eliminated most efforts to use the term (or even the term 'ethnicity') as a variable in studying racism. Moreover, this 'race-neutral" or 'color-blind' approach to the world is frequently presented as deeply embedded in French political culture since at least the Revolution, except, of course, during the catastrophic Vichy era.

The discursive displacement of race has made difficult the development of anti-racist organisations and policies.

When Algerian subjects began to move to France the spatial structure which was a practical consequence of this radicalized division was replicated there. Further, Achille Mbembe, commenting after the riots across France in 2005, notes that:

The Code de l'Indigénat was elaborated to govern the colonies. By its very nature, this was a government of extraordinary powers based on state racism [...] The legal philosophy underlying the Code de l'Indigénat - and its corollary state racism—is now being brought back to metropolitan France. That philosophy is being deployed in the struggle against categories of person in France judged undesirable (illegal immigrants, undocumented aliens, refugees).

(2009: 52-53)

Indeed, the mode of policing all Africans classed as immigrants, documented or not, approaches that of the Code. Paul A. Silverstein explains that,

the French government has responded to the 'crisis' of the cités with increased police intervention, predicating urban renewal on social and political quiescence. Reacting to the growth of 'lawless zones in which the law of the Republic is totally absent', the 1995-1996 plans added 200 plainclothes inspectors to the already expanded suburban security forces to 'penetrate the milieux of delinquency'. In 1999, Socialist Prime Minister Lionel Jospin took these surveillance methods 
one step further, mobilizing 13,000 additional riot police (CRS) and 17,000 military gendarmes to patrol these same 'sensitive urban zones,' and thus effectively completing the militarization of the French suburbs [banlieues].

It is in these governmental practices that we can see played out the distinction between 'man' and Other, between citizen and subject.

This means that Beurs are caught up in a fraught postcolonial structure, struggling to find a way to live in their country of birth, in which they are often seen as not properly French, while also looking for ways to relate to the homeland of their parents where, also, they often find themselves rejected. As Gabriele Marranci writes: 'In France beurs are seen as immigrants, even if they often have a French education and nationality. On the contrary, in Algeria they are seen as French or, if worse comes to worse, as "traitors" to Algerian culture' (2000: para. 8). Marranci expands on this latter point:

The beurs' experiences (in particular for girls) of going back to Algeria-for instance, during the holidays with their parents - are sometimes really traumatic. For example, beur boys are often called by offensive names, such as 'l'émigré', but the beur girls are referred to amjah (lost) and merula (a woman of loose morals).

(2000a: para. 8)

This sense of rejection and homelessness has translated into a determination to be acknowledged as French, albeit as differently French from those who claim a Gallic heritage.

There is a long history of male Algerian migration to France for work. In the years before World War 1 there were around 10,000 Algerians working on the docks, in mines, and in factories. In the years after the war this number swelled to around 80,000. During this period there started the tradition of the spatial segregation of North African immigrants which still continues. By 1962, at the end of the Algerian War of Independence, there were about 350,000 Algerians in France, a figure that had risen to 800,000 two decades later. These industrial workers who underpinned the expansion of Les Trentes Glorieuses were accommodated in the 1950s in bidonvilles, that is shantytowns, on the outskirts of many French cities. Over time these bidonvilles were supplanted by new high-rise blocks of apartments that became characteristic of, 
and synonymous with, the peripheral suburbs known as banlieues. It was here that the Beurs were born and raised.

The 1980s saw the rise of the Beurs as a visible movement demanding civil rights and the public acknowledgement of their unique position in French society. Perhaps the best example of this new visibility was the first so-called Marche des Beurs, officially called 'la marche pour l'égalité et contre le racisme' [The March for Equality and Against Racism], which started in Marseille in October and concluded in Paris in early December 1983 with anywhere between 60,000 and 100,000 participants. The Marche des Beurs was conceived as a reaction to the publicity surrounding the first of the banlieue riots, the 'rodeo riots', which took place in 1981 in the banlieue of Les Minguettes on the southern outskirts of Lyon. The rodeo riots were so-called because they involved the stealing and drag-racing of cars which were subsequently incinerated. Since then, as Anne Sa'adah notes:

Urban riots have become regular occurrences in France. Les Minguettes [...] erupted in the early 1980s; Toulouse did the same in December 1998. In the intervening years, the problem neighbourhoods of many urban areas made news by making trouble, with an important wave of urban violence in the early 1990s.

(2003: 212)

At the heart of this unrest was the refusal of the Beurs to accept their racist identification as immigrants.

In May 1981 François Mitterrand was elected president on a platform that included more lenient treatment for African migrants and their descendents. Bleich explains that:

The opening years of the new Socialist administration of 1981 [...] coincided with—and helped contribute to-rising immigrant consciousness and experimentation in government policies towards immigrants. Whereas Giscard d'Estaing had sponsored a variety of illiberal policy initiatives, Mitterrand and the Left embarked on a more generous path, regularising 130,000 illegal immigrants, restricting powers of expulsion, and lifting a ban on foreigners forming officially recognized associations.

(2004: 173) 
This ban had been in place since before the start of World War 2 when its purpose had been to stop Jewish and anti-Nazi refugees from Germany inflaming relations between the two countries. The abrogation of this ban led to a flowering of support associations among Beurs and, indeed, enabled the organisation of the Marche des Beurs. Overall, the Mitterrand changes made Beurs more certain of their presence by, for example, stopping the expulsion of non-citizens born in metropolitan France. There has, though, been a retreat from the moves made by the Mitterrand government towards multiculturalism. Silverstein notes that:

France has to a great extent maintained an assimilationist approach in its immigration policies. Fleeting experiments in multicultural education and pro-immigrant quota systems, despite their initial support by the socialist government in the early 1980s, have since received volatile criticism from almost all fronts, with most politicians fearing that any support given to immigrant community-based initiatives will result in the creation of ethnic ghettoes, if not ethnic separation.

(2004: 29)

For the established French population, and for the secular French state, the sticking point has been the complex imbrication of Islam and culture in the ways of life of North Africans.

At the same time that the Beurs were refusing their marginalization in French society, so there was a marked increase in institutional racism. This is most obviously evidenced in the career of Jean-Marie Le Pen. Le Pen founded the Front National in 1972. However, it found little traction among French voters until the municipal elections of 1983. In the 1984 elections for the European Parliament, the Front National gained $10 \%$ of the vote and Le Pen, himself, won a seat. In the 1986 elections to the French National Assembly, which François Mitterrand's government held using proportional representation, thirty-four Front National candidates gained seats. As racist anxieties increased in 2002 Le Pen made the second round run-off in the French presidential election forcing voters to choose between him and the right-wing incumbent, Jacques Chirac. The rise of the far-right has led to a decline in the visibility of the Beurs as French minorities fight to preserve what rights they have rather than struggling for more. The most high profile anti-racism organisation, SOS-Racisme, was founded in 1984 to counteract the growing significance of the Front National and the increasing belief among its supporters that behaving in a racist way was acceptable. 


\section{Rachid Taha and the Postcolonial Experience}

Typically of Beurs, Rachid Taha describes himself as both French and Algerian: 'Speaking on British television in 2005 the singer tried to convey the complexities of his personal identity by explaining that although he will be Algerian to the end of his days, on a dayto-day level he is French' (Evans \& Phillips 2008: 26). In his autobiography, the title of the final chapter carries a similar sentiment: ‘Algérian pour toujours, et Français tous les jours' [Algerian forever, and French everyday] (Lacout \& Taha 2008). Taha formed his first group, Carte de Séjour, which translates as Residence Permit, in 1981. It was a manifestation of the new militancy of Beurs which, as we have already seen, evolved in a variety of ways. From the beginning, Carte de Séjour's music expressed the feelings of métissage, of what in English is called hybridity, that of necessity characterize the experience of Beurs. As in Britain, métissage, thought in terms of, for example, interracial relationships, were disapproved of during the colonial era (Young 1995). Dina Sherzer writes that:

Métissage is a term invented during the colonial period, as mixed-blood children were born from relationships between French men and Asiatic, African and North African women in the colonies. It had negative connotations, implying miscegenation, mongrelization and impurity.

(1998: 105)

The fear, which has returned - if it ever went away-is that hybrid relationships will dilute the racial stock, and the presence of numbers of people from the post-colonies will debase the cultural capital of the French republic.

However, and here we come to the key element in Taha's work, from the perspective of the minority and the subaltern, métissage is important in overturning the power of the colonizer based in the binary structure of colonizer/colonized. As Homi Bhabha explains: 'The social articulation of difference, from the minority perspective, is a complex, on-going negotiation that seeks to authorize cultural hybridities that emerge in moments of historical transformation' (1994: 3). The authorization, and indeed legitimation, of cultural hybridities, of métissage, undermines the binary integrity on which the power of the colonizer rests. Bhabha goes on to remark that: 
The 'right' to signify from the periphery of authorized power and privilege does not depend on the persistence of tradition, it is resourced by the power of tradition to be reinscribed through the conditions of contingency and contradictoriness that attend upon the lives of those who are 'in the minority'.

(1994: 3)

As we shall see, this describes well how we may understand Taha's corpus. Taha's work acknowledges the differences between Algerian and French cultures while also finding ways to merge them productively. In doing so, Taha makes a statement about the worth of Algerian culture in relation to French culture and, in mixing the two, threatens the purity of French culture. It is this transformation which makes traditionalists like Le Pen most anxious.

In his autobiography Taha tells us that he was born in Oran but was brought up in Sig, a village fifty-four kilometres from the city, until the family moved back to Oran. Taha was born in 1958, during the War of Independence. In Sig, his father was a shepherd. In Oran he worked in a factory. In this movement between rural and urban, Taha's father experienced the impact of colonial modernity. Taha tells the story of an uncle who, having fought for the French in World War 2, returned to Algeria to find that nothing had changed, that Algeria was still ruled by French colonial racism. He joined the Front de liberation national (FLN) [National Liberation Front]. Hunting him down, the French military took one of his brothers, another of Taha's uncles, and tortured him. Finally, when he would not talk, the French murdered him by dropping him into his village from a helicopter. Taha's father left to work in France in 1968 followed in 1971 by Taha and his mother. Taha was, then, thirteen and well understood the practices of French colonialism when he moved to France. The family lived in Sainte-Marie-aux-Mines in Alsace and then for a short while in Lépanges-sur-Vologne in the Vosges. In France, at school, the colonial experience continued, Taha was subjected to racist taunts. ${ }^{2}$

By the time the family moved to Lyon around 1981. There, it seems, they lived in Les Minguettes (Taha et al 1987), where, we should remember, the rodeo riots took place in that same year. Taha had become a travelling salesman. He then started working in a factory where he met the Moroccan brothers Mohammed and Moktar Amini with whom he founded Carte de Séjour. Around this time Taha also ran club nights called Les Refoules. While this word is often translated as 'the repressed' or even 'the rejects' it is linked to the English-language legal term 
'refoulement' and carries connotations of refugees being sent back to the country from which they are desperate to escape. For Taha calling his club Les Refoules no doubt suggested to the Beurs their sense of being caught between two countries each of which rejected them for opposite reasons. It also, at a much more local and immediate level, referred to the racist refusal by many night clubs to allow in people of North African and African backgrounds. Taha 'played mash-ups of Arabic pop hits over tracks by the likes of Led Zeppelin and Kraftwerk' (O'Brien 2012). That is, Taha was already developing forms of musical hybridisation and resolving that hybridisation in dancing, a theme which has continued through his career.

Carte de Séjour lasted for nine years, dissolving in 1989 after a tour of Germany. In that time the group released a self-titled EP (1982) and two albums, Rhorhomanie (1984) and 2 et 1/2 [2 and 1/2] (1986). ${ }^{3}$ In addition to the Armini brothers the group included Djamel Dif and Éric Vaquer who was soon replaced with Jérôme Savy and, sometimes, Jallane Abdelhak from the group Jil El Ghiwane who played the oud. Much of their material was in Arabic, indeed all of 2 et 1/2 except for their version of Charles Trenet's 'Douce France' [Sweet France] which will be discussed later. The Arabic basis of their lyrics, coupled with a punk sound and AfricanAmerican funk rhythms, suggests a hybridity that locates the Beurs as the group's main audience. One of the tracks on Rhorhomanie was titled 'Zoubida' and was an attack on fundamentalist Islamic practices of arranged marriages. It so happens that 'Zoubida' is a name commonly associated with Beurettes, female Beurs (Abdel-Jaouad 2010: 129). Ironically, in 1991 Vincent Lagaf had a hit with a different song of this title, a song often considered in bad taste if not racist, a parody of 'Sur le pont de Nantes', which featured a young Beurette. The connection between Carte de Séjour and Beur politics was formalized with one of their more high profile concerts in the Place de la Bastille at the end of the 1983 Marche des Beurs (AbdelJaouad 2010: 129). Hédi Abdel-Jaouad remarks that: 'From its inception, Carte de Séjour has fused and "métissaged" sounds, infusing "French Rock'n'Roll" with Oriental and AfricanAmerican tunes and lyrics' (2010: 129). However, the group certainly also looked for a more mainstream audience and, at some point in the first half of the 1980s it seems they opened for the popular French rock group Téléphone at the Palais des Sports. ${ }^{4}$ After Carte de Séjour broke up Taha became a solo artist making numerous albums beginning with Barbès in 1991. 


\title{
'Rhorhomanie'
}

\begin{abstract}
Abdel-Jaouad argues that:
An examination of Carte de Séjour's early songs reveals their depth of commitment in addressing concerns and sensibilities rarely engaged by mainstream musicians. They cast their biting social commentaries and serious issues in playful, ironic and sarcastic language, as best illustrated in their album Rhorhomanie.
\end{abstract}

(2010: 129)

At the same time we need to acknowledge Taha's assertion that Carte de Séjour was not a group with a cause; they did not make politically driven music. Taha writes: 'Notre ambition n'était d'ailleurs pas de faire des chansons contestataires. On aimait le rock, on avait plaisir à chanter du rock et on voulait faire du rock. Point final'. [Our aim was not necessarily to make protest songs. We loved rock, we enjoyed singing rock and we wanted to make rock. That's all] (Taha \& Lacout 2008: 106). Taha argues that the kind of music the group made was a function of their positioning in French society. Beginning from the claim that: 'Le rock est une musique d'immigrés' [Rock is a music of immigrants], Taha goes on to explain: 'Pour nous, le racisme (ou l'antiracisme) n'était pas une "cause" (une psy-cause), mais notre lot quotidian, ce que nous vivions chaque jour, chaque soir dans notre chair' [For us, racism (or antiracism) wasn't a cause (or an 'obsession'), but it is our everyday life, what we lived each day, each night in our flesh] (Taha \& Lacout 2008: 106). For Taha, rock music, as the music of immigrants, is the natural musical form for the expression of the views of those racially oppressed by the dominant order. Taha's personal model was the Clash. I shall say more about this when I discuss Taha's Arabic revisioning of the Clash's 'Rock The Casbah'.
Abdel-Jaouad goes on to explain that:
This title [Rhorhomanie] is meant as a provocation: "Rhorho" is a pejorative term for "Arabs". It alludes to the Arab phoneme rho which sounds barbaric to a French ear and is thus deemed 'unpronounceable'.

(2010: 129)

What, then, can 'rhorhomanie' — an English translation would be 'rhorhomania'—mean? The term suggests some kind of pathological preoccupation with Arabs, seen in the most negative 
way. It could allude to the French racist preoccupation with identifying people of Arab, or more generally North African, background and demanding their deportation to Algeria. However, it could also refer to the way that people of North African background have been socialized in France to see themselves - that is, through the prism of French racism. The use of the term 'rhorho' in the title of an album made by a predominantly Beur group suggests an appropriation of this negative term similar, for example, to the gay appropriation of 'queer' or, and this is much close to the sense of the lyrics of the track with the same name as we shall shortly see, the African-American appropriation of 'nigger'; that is, an appropriation which transforms a negative label into a positive assertion of pride.

With this in mind, let us examine the title track in detail. The lyrics are primarily in a combination of French and Algerian Arabic, with occasional phrases in English. Already, then, the song assaults the French preoccupation with the purity of the French language. Already we have a statement of hybridity. In their discussion of the song, Mohamed Meouak and Jordi Aguadé describe the lyrics as an example of what they call 'langues en contact' [languages in contact] (1996: 160). Giving a greater sense of cultural depth to the linguistic hybridity, AbdelJaouad quotes Richard Dederian: 'Unlike most North African groups Carte de Séjour's music was primarily in Sabir - a mixture of French, Arabic, and an assortment of other languages spoken by North African immigrants' (2010: 129). Dederian may here be referring to the liner notes of Ramsa where, under the heading 'Language', we find:

We talk in Sabir. It is the ancient language of the Mediterranean Sea and its ports. The sounds are Arab, English, Spanish, French, African [...] In France today Sabir is Rhorho. You take words from everywhere.

(Taha et al 1987)

Historically, Sabir was a lingua franca — indeed, the language originally called lingua francaused as a trading language around the Mediterranean basin. It was a pidgin language, that is, it evolved out of the languages spoken by the linguistic groups in contact with the imperative of communication. Mikael Parkvall dates the development of Sabir to around the thirteenth century (2005a: para. 2). Alan D. Corré writes that it 'surviv[ed] until the nineteenth century, when it disappeared with hardly a trace, probably under the onslaught of the triumphant French language' (Parkvall 2005b: para. 1). French was triumphant because of the success of the French 
colonial ventures in North Africa. Sabir was replaced by the linguistic developments occasioned by the colonial interactions between the language of the colonizer and the colonized. This was a relation of power rather than trade. It is unclear who wrote the liner notes for Ramsa, though the 'we' suggests that they come from the group, but describing the language of Rhorhomanie as Sabir disavows the linguistic consequences of colonialism to assert a longer, and more egalitarian, heritage for the linguistic mixing on the album. Bhabha argues that: 'Hybridity is the sign of the productivity of colonial power, its shifting forces and fixities; it is the name for the strategic reversal of the process of domination through disavowal (that is, the production of discriminatory identities that secure the 'pure' and original identity of authority' (1994: 159). The claim that the language mixture used on Ramsa is 'Sabir' is an assertion of such subaltern hybridisation.

This linguistic mixing is also the language of the Beurs themselves as second-generation French residents. In his discussion of a number of Beur novels, Silverstein comments:

Language [...] serves as a point of generational contention. Although their maternal language is Arabic or Tamazight [a Berber language], Beur protagonists generally converse, both inside and outside the home, in French. Sometimes by their French responses, it is clear that they understand only a small percentage of their parents' language. Moreover, if the characters do speak Arabic or Tamazight at home, their language is portrayed as always already confounded with French phrases and locutions.

(2002: 196)

This rhorho language is, then, actually the hybrid language of the Beurs themselves, an expression of their own interstitial positioning between French and Algerian cultures.

There is a further way of thinking about the productive hybridity of the rhorho language. Frantz Fanon suggests that: 'To speak means to be in a position to use a certain syntax, to grasp the morphology of this or that language, but it means above all to assume a culture, to support the weight of a civilization' (1986: 17). He writes also that: 'Every colonized people [...] finds itself face to face with the language of the civilizing nation, that is, with the culture of the mother country' (1986: 18). He argues that the taking on of the colonizer's language 'whitens' the colonized. But this, of course, is metaphorical. The colonized takes on the language and culture of the colonizer but, as Taha points out in the quotation above, the colonized continues to live in 
his or her skin. In some countries the negative term for such people is 'coconut'-black on the outside and white on the inside. From this point of view, the linguistic hybridity of Rhorhomanie can be read as an attempt by the subaltern to undermine the homogenising power of the French language and the mission civilisatrice [civilizing mission]. Arabic erupts into French and relativizes its apparent certainty.

The lyrics begin with a question in Algerian Arabic: 'Chkoune liguelle?' Translated in the liner notes as: 'Who has said?' The first time the question continues: 'Les Kahlouches c'est louche'. The second time the question ends: 'Les Rhorhos y'en a trop'. 'Kahlouches' is a Franco-Algerian word, a very pejorative way of identifying black-skinned Africans. These people are 'louche', disreputable. The speaker here would appear to be an Arab Algerian. The claim that there are too many Rhorhos would suggest a racist French speaker complaining about the numbers of North Africans in France. Read together the statements suggest that racism is pervasive, as much a part of Algerian life as French life. These statements, the lyrics tell us, are examples of Rhorhomania - perhaps a way of describing generalized racism. With a punk funk rhythm the lyrics list and endorse important black artists including James Brown, Jimmy Cliff and Jimi [in the transcribed lyrics as Jimmy] Hendrix and also the celebrated Egyptian singer Oum Kelthoum. Later in the song the Algerian musical form rai is mentioned along with two of its exponents, Fadela and Bellemou. The lyrics enjoin us to 'danse d'aujourd'hui' [dance today]. Dancing is being recommended not so much as a solution to racism as an alternative. The lyrics, with their transgressive use of proscribed identifiers, and their listing of great musical artists, are excessive - an example of Bhabha's productive hybridity that escapes the confinement of the colonizer's language. Reflecting this, dancing, it seems, as at Les Refoules, offers the

opportunity of an ecstatic pleasure that transcends the quotidian racism in which the Beurs live their lives.

\section{'Douce France'}

The track which made Carte de Séjour's reputation among mainstream French was on their second album, 2 et 1/2. 'Douce France' was the only track in French on that album and it was the only cover. It was composed and sung by Charles Trenet in 1943 during the Occupation. He recorded the song in 1947. The lyrics evoke the gentle, or sweet, France of the singer's 
childhood conjured up as 'Cher pays de mon enfance' [Dear country of my childhood]. This France is of small villages and walks to the local school. It is a romanticized country of preindustrial and rural innocence. Sung during the Nazi occupation, the song functioned as an agonising evocation of what the French felt had been lost in the war. Sung after the war, the song suggested a yearning for a less complicated world, a world before the modernising thirty glorious years of post-war industrial and urban expansion.

Trenet was included in the pantheon of chansonniers, singers of chansons, a French tradition which mythically goes back to the troubadours of the Middle Ages. Indeed, Trenet references this heritage, through a more immediate reference to the title of a collection of poems by Paul Verlaine, in the first verse of 'Douce France' when he remembers that, on that walk to school, 'Je chantais à pleine voix/Des romances sans paroles/Vieilles chansons d'autrefois' [I would sing loudly/From Songs Without Words/Old songs of other times]. By the 1970s Trenet's reputation had reached a nadir amid questions about whether he had been a collaborator during the war. In part this related to the way that 'Douce France' was understood to evoke 'valeurs éternelles', the eternal values of the French nation. To quote Christopher Lloyd,

as Laurent Gervereau notes, in the nationalist domain, Vichy and Resistance propaganda overlaps, since both claim to speak for the nation and its eternal values; and the observation extends to cultural representations, so that a famous song like Charles Trenet's 'Douce France' 'reprend une terminologie pétainiste alors que certains y voient une allusion à la Resistance' [adopts Pétainist terminology, though others see in it an allusion to Resistance].

(2003: 167)

However, the 1980s saw his rehabilitation. As David Looseley writes:

Trenet's consecration did come eventually. In 1982, the year of his application to the Académie [which was rejected], he was adopted by the new Socialist government as a kind of nationalcultural mascot: Légion d'honneur conferred by Mitterrand in May 1982, Commander of Arts and Letters awarded Jack Lang (who had also supported his candidacy to the Académie) the following November, participation in Mitterrand's inauguration of the Zénith in 1984.

At the same time that Mitterrand was attempting to improve the situation of Africans in France, and increase their acceptance, and also move French culture towards a form of multiculturalism, 
he was also reinforcing the core French tradition, a tradition emphasized by the Front National in the form of those 'valeurs éternelles' which hearers found in 'Douce France'.

Thus, when Carte de Séjour covered 'Douce France' in 1986 the track was not just a jewel from France's wartime past, it was very much a part of a current debate about the form that France's culture should take. The nostalgia it evoked was of two quite different forms. There was a nostalgia for a war, now known to have been won, fought between what were thought of by many, incorrectly, as white people. And there was the nostalgia offered by the song for a mythical simpler time, a time when France had a homogeneous culture and a white population. It is not surprising, then, that Carte de Séjour's Arabized version of the song was deeply shocking to many people..$^{5}$ Taha gives the French lyrics an inflection characteristic of Arabic singing while the instrumental backing includes an oud and the prominent use of a darbouka, both instruments immediately recognisable as North African. Looseley describes the Carte de Séjour version in terms of métissage and locates it within world music but the cultural work done by this version is much more significant than this (2003b: pp. 50-51). Rodney Hall and his coauthors describe Carte de Séjour's version as 'a brilliantly ambiguous rendering'. They explain this interpretation:

\footnotetext{
In the eyes of many ordinary French people, the Beurs are an alien presence. Carte de séjour's rearrangement of Trenet's romantic song, bringing in a rock beat and Arab instrumentation, may seem at one hand to confirm this alien quality. At another level, however, it reveals the genuine attachment of the Beurs to the country in which they have grown up.
}

(Hall et al 1995: 271)

At the same time, this version is a challenge to traditional French culture. Its appreciation requires the acceptance of Arab influences in that culture. Martin Evans and John Phillips come closer to the political force of the Carte de Séjour version when, after suggesting that Carte de Séjour's name was itself a response to the new-found popularity of Le Pen's Front National, they comment that:

Carte de Séjour's video [...] is one of the most subversive of all time; a statement about postcolonial society, it showed the band strumming in a late-night Parisian café, surrounded by old French couples serenely waltzing to the tune. Its message was that there was no going back. 
Whatever Le Pen might do or say Algerian immigrants and their descendents are an inescapable part of France.

(Evans \& Phillips 2008: 28)

And more, they transform French culture, opening it up to the influences of the cultures of those the French colonized. Indeed, Carte de Séjour's Arabising of 'Douce France' paved the way for a number of similar Arabized revisionings. In 1999, thirteen years later, Natacha Atlas released an Arabized version of 'Mon amie la rose' [My friend the rose], first recorded by Françoise Hardy in 1964. This climbed to number 19 on the French chart. In that same year, the rai artist Faudel covered Jaques Brel's 'Ne me quitte pas' [Don't leave me] on a tribute album to the great chanson singer. Atlas covered the same song on her 2001 album, Ayeshteni. By this time, as Atlas' chart success indicates, Arabized versions of classic French language songs was considered acceptable and no longer noteworthy.

Bill Ashcroft offers a way of understanding the power invested in Carte de Séjour's version of 'Douce France'. Working over Homi Bhabha's idea of ambivalence, Ashcroft argues that,

ambivalence may be regarded as a much more active feature of post-colonial subjectivity. It may be seen to be the ambivalent or 'two-powered' sign of the capacity of the colonized to 'imitate' transformatively, to take the image of the colonial model and use it in the process of resistance, the process of self-empowerment. (original emphasis)

The ambiguities that commentators find in Carte de Séjour's reworking of 'Douce France' are directly related to the imitative transformation of Trenet's original. Once again, but in a different manner to 'Rhorhomanie', Taha, and Carte de Séjour, have utilized hybridity (métissage) to confront the contradictions in French society. In doing so, Carte de Séjour's own version of 'Douce France' is available for multiple interpretations.

Commenting on a scene in Salman Rushdie's Satanic Verses where the Indian actor Gibreel Farishta dresses up in the clothes of the ex-colonial land-owner Sir Henry Diamond, Bhabha writes that: 
What is more significant, and in tension with this exoticism, is the emergence of a hybrid national narrative that turns the nostalgic past into the disruptive 'anterior' and displaces the historical present—opens it up to other histories and incommensurable narrative subjects.

(1994: 240)

Similarly, the dressing up of 'Douce France' in an Arabized musical form opens the possibility not just for a revisioning of the French 1980s present but for a new recognition by the French of the role Algerians played in the Second World War and, indeed, of the French debates about citizenship and subjectivity that, as we have seen, were central to the relationship of French republicanism and colonialism. In this sense, the polysemic productivity of Carte de Séjour's 'Douce France' also challenges the nostalgia of the lyrics of 'Douce France'. That pastoral idyll outlined in Trenet's lyrics was made possible by the French colonial depredations in North Africa.

There is another place in Taha's work where 'Douce France' appears. In 1994 Taha released a track titled 'Voilà Voilà' [Here Here]. It was an unexpected dance hit in Britain, where it reached number 91 on the pop chart and also in the United States where it climbed to number 35 on the dance chart. Over an infectious dance beat, Taha intones a warning in French about the rise of racism. 'Partout', he sings, 'ils avancent' [Everywhere, they rise]. With what may be an allusion to the Holocaust Taha tells us that the lesson was not enough. We must be on guard against racists who blame strangers as the cause of our problems. They advance in 'douce France'. Here the echo of Trenet's song offers Taha a way to describe a France without racism. The irony here is that it is the 'valeurs éternelles' implicit in Trenet's song which the Front National champion. Once again, Taha is appropriating the song, this time to suggest that one of France's eternal values is precisely its lack of racism - a claim commensurate with the Enlightenment argument that all men are equally equal. It is also not surprising, we should note, that Taha couches his antiracist message in a dance track. Once again, for him, the physical pleasure of dancing, of the body in dance, transcends the divisive preoccupation with superficial skin colour.

\section{'Ya Rayah'}


In order to understand fully Carte de Séjour's 'Douce France', and Taha's later use of the term in 'Voilà Voilà', we need to acknowledge another of Taha's revisionings. In 1997 Taha released a version of 'Ya Rayah'. This song was written and first recorded by Dahmane el Harrachi in the late 1960s. Taha's version reached number 11 on the French chart. 'Douce France' and 'Ya Rayah' are in an important sense complimentary. As Christa Jones remarks: 'À la 'Douce France' de Charles Trenet répond 'Ya Rayah', le "Partant" qui parle de la douleur de l'exil de la première generation des immigrés qui compent toujours retourner en Algérie' [Ya Rayah' compliments 'Douce France,' we find in it the "leaving" which tells of the pain of exile of the first generation of immigrants who always counted on returning to Algeria] (2009: 114). Where 'Douce France' is the song of home, of the nostalgia for a home that is lost, 'Ya Rayah' is the song of the wanderer, the migrant, yearning to return to the home they have left behind. Born Abderrahmane Amrani, Dahmane was brought up in the Algiers suburb of El Harrach. He took the name Dahmane el Harrachi because his father was the muezzin of the Great Mosque of Algiers and disapproved of his son pursuing a career in popular music. In 1949, when he was twenty-three, Dahmane moved to France where he spent the rest of his life entertaining the Algerian migrants. In 1980 he died in a car crash near Algiers.

Dahmane sang in the chaabi genre. Chaabi evolved in Algiers in the late $19^{\text {th }}$ century. It was a people's music, folk music; the secular music of the casbah. Chaabi was acoustic. It combined some Western instrumental influences with the music of Andalusia:

A typical song features mournful, Arabic/Berber vocals, set against an orchestral backdrop of a dozen musicians, with violins and mandolins swelling and falling to a piano melody and the clap of percussion beats. While it shares many set themes with Flamenco - love, loss, exile, friendship and betrayal, Chaabi is part of a deeply conservative tradition and its lyrics often carrying a strong moral message.

(Anon. 2012: para 3)

This was the music of the first generation of post-war Algerian migrants to France.

'Ya Rayah' is one of Dahmane's best-known songs, a classic among those for whom it was written. It is a song of sadness and loss. The traveller, the migrant, is told that their journey will end in failure and exhaustion. It is a song of disillusionment and disappointment. More, it 
can be understood in terms of the Algerian Arab notion of mehna. Tullia Magrini explains this concept:

One of the recurrent themes of the female lament is the mehna, a polysemic concept operating a rather explosive alliance in the experiences of pain and pleasure. The root MHN in Arabic evokes the idea filling something up until it cracks and overflows. It refers to the force-feeding of suffering, but also of love and alcohol. The trials recalled, of different origins, are always excessive.

(Virolle 2003: 222)

Mehna describes that exquisite moment of excess when pain and pleasure spill into each other. 'Ya Rayah' suggests the experience of those migrants who went to France for work hoping to find riches and return to their villages in Algeria only to discover that they were trapped in a cycle of hard and unrelenting grind for little profit. These were the people who found themselves living in the bidonvilles and the banlieues.

Paraphrasing a 1988 article by Abdelmalik Sayad, the most influential sociological investigator of Algerian migrant life in France, Pierre Bourdieu and Loïc Wacquant write that immigrant workers,

are changed in and by migration: they become irrevocably distanced and dis-located [sic] from their originating milieu, losing a place in their native circle of honor without securing one in their new setting; they acquire this false and disjointed double-consciousness that is a source of both succour and pain; they are consumed by doubt, guilt and self-accusation, worn down by an 'unjust and uncertain' battle with their own children, these 'sociological bastards' who personify the horrifying impossibility of the 'return home'.

(2000: 176)

These people are the parents of the Beurs; the Beurs themselves are Sayad's 'sociological bastards'. 'Ya Rayah' is the wail of anguish of the Beurs' parents. For Taha to rework this song, and to do it in a updated form that is best described as rai, is a similar travesty for his own parents' generation as Carte de Séjour's revisioning of 'Douce France' was for those French who were emotionally connected to the Second World War. 
Rai developed in Algeria, mainly in Oran, in similar circumstances to chaabi but a generation or so later. Oran has a more cosmopolitan history than Algiers and rai has always had closer links with Western popular music. Looseley writes that:

Raï began in and around Oran at the turn of the century as part of a popular oral tradition and by the 1960s was celebratory acoustic music. Then, a new generation began fusing it with Western pop, which was flowing into the country after independence in 1962. (2003b: 51)

While the influence of Western music on chaabi was mostly confined to instrumentation, rai, while remaining acoustic, increasingly included Western rhythmic and melodic influences. Two decades later, as Chris Nickson tells us:

In the early 1980's, Algerian producer Rachid Baba Ahmed revolutionized the rai tradition by deploying electric guitars and basses, keyboards and drum machines. This plugged-in makeover of a previously acoustic tradition transformed rai into a youthful sound, much like rock in the West.

(2001: para. 15)

Unlike the conservatism of chaabi, rai,

used the plain language of the street to speak out on behalf of a whole generation of young Algerians who were fed up with the hypocrisy and corruption of their Arab socialist rulers, with the incessant moralising of fundamentalist imams and social leaders and with the general misery of atrocious housing, lack of jobs or opportunities, sexual frustration and the pervasive joylessness of life in 1980s Algeria.

(Morgan 2011: para. 1)

The term 'rai' is often translated as 'opinion'.

The first festival devoted to rai in France took place at Bobigny, on the outskirts of Paris, in 1986. It was opened by Cheihka Remitti, who had grown up singing at the same time as rai getting established, and starred some of the most prominent singers of the 1980s, including Cheb Khaled and Cheba Fadela. The landmark concert for the penetration of rai into more mainstream French society was staged at Bercy in September 1998 with Khaled, Faudel and Taha. Aiming at a crossover market, rai was increasingly produced with a regularized beat more characteristic of Western popular music. ${ }^{6}$ The tracks on the album of the Bercy concert, 1,2,3, Soleils, have just such an arrangement and the album went gold on its sales in France. ${ }^{7}$ 
In France, rai was intimately linked with the experience of the migrant generation. Marranci argues that:

It is a 'music of return.' In fact, rai music allows the immigrants to carry out the 'myth of return' that is often impossible to realize. This is possible since rai in Paris often operates as a 'musical metaphor': from the love for a woman to the love for the immigrant's homeland. If the chaabi texts tell about the problems of immigration, rai texts remind the immigrants why they abandoned Algeria, the people that they love in Algeria, sometimes the Algerian youth. Therefore rai music confirms to be an important tie between immigrants and Algeria, a tie that may live again through rai music.

(200b: para. 11)

Rai in France conjures up for the Algerian migrants a sense of nostalgia and loss. As Parvati Nair notes, acknowledging the work of Marc Schade-Poulsen: 'In raï, ... lyrics of desire or mehna (suffering and longing) function as a veil for the restless strivings of the immigrant and the socio-economically underprivileged' (2007: 76). In this migrant context, then, the feeling of rai is similar to that of the older chaabi while the music sounds more Western than that of chaabi. The audience for rai, then, straddles the immigrant generation and the Beurs. For Taha, even though he spent his early years in Algeria, and for the Beurs more generally, returning to Algeria would not be returning home. Algeria as home has always already been lost for them.

The two versions of 'Ya Rayah' speak to the two different generations. Dahmane's chaabi original resonates with the generation which migrated to France and found itself trapped. This generation yearns nostalgically for a return to the now-lost Algeria where its members grew up. Taha's version uses an electrified hybrid instrumentation drawn from Western popular music as well as traditional North African instruments. Dahamne's lyrics are sung with an Arabic intonation but subjected to a Western beat. Taha's revisioning appeals to a generation mostly born and brought up in France for whom métissage is their way of life. These are people who have hardly, if ever, known Algeria. This generation feels caught between a France which is home but which rejects them and an Algeria which is their heritage but which is unknown and which, also, rejects them. There is much, though, that is common between Dahmane's and Taha's versions, not least mehna, the terrible yet exquisite feeling of yearning that both recordings evoke. This is the same feeling produced in different ways by Trenet's and Carte de 
Séjour's 'Douce France' for the French generations who feel that a comfortable, and simpler, France has been lost. The chart success of Taha's version of 'Ya Rayah' suggests that its message of agonising and sublime loss, of a feeling of uncanniness in one's home country, also appeals to a younger, white French generation who know that France is changing with the necessary acceptance of the Beurs and, indeed, of their children, but do not know how to feel at home in this new France.

\section{'Rock El Casbah'}

If Carte de Séjour's 'Douce France' and Taha's 'Ya Rayah' offer reflections of each other from two different traditions, Taha's version of the Clash's 'Rock The Casbah' confronts the Western and Algerian Arabic traditions to produce a synthesis which was a danceable resolution. Taha's 'Rock El Casbah', with the lyrics translated into Arabic, first appeared on his album Tékitoi which was released in 2005. The Clash's version can be found on their fifth album, Combat Rock, released in 1982. As a single in Britain the track reached number 30, in the United States it climbed to number 8 on the Billboard chart. Along with the Sex Pistols, the Clash were one of the most prominent groups to come out of the British punk movement of the late 1970s. However, unlike the Pistols, the Clash had a positive political philosophy, informed by Marxism, of identification with, and support for, the oppressed. Joe Strummer, the group's lead singer and composer of many of their tracks, saw himself mythically as a rebel, an outlaw pursued by the state for his beliefs. As Stephen Thomas Erlewine puts it: 'The Clash copped heavily from classic outlaw imagery, positioning themselves as rebels with a cause' (2012: para. 1). This was reflected in the group's liking for roots reggae and their covering of tracks like Willie Williams' 'Armagideon Time' and the garage rock song 'I Fought The Law'.

The lyrics tell a story about an Arab sharif, driving a Cadillac, who refuses to allow his people to play rock music. Instead, they play a localized version on local instruments. The music is banned using Islam as the justification: 'By order of the prophet/We ban that boogie sound'. The music is coming from the casbah so the sharif orders his jet fighters to bomb it. However, the pilots start enjoying the music instead. Donald A. Guarisco explains that:

The lyrics, penned by Joe Strummer, were inspired by a news report of Iranians being flogged for the crime of owning a disco album and create an amusing fantasy where a disco-hating sharif is 
defied by everyone from the citizens to his own air force as he tries to stamp out 'that crazy Casbah sound'.

(2012: para. 1)

The lyrics express the class oppression against which the Clash fought, but this time in an Arab country. The lower classes, living in the casbah, enjoy the popular music; the sharif dislikes it. The song also signals the impact of American neoimperialism. The sharif is driving an imported American car and one can surmise that his jets are either bought from the United States or some other Western power, possibly France. The song can be read as an attack on Islamic fundamentalism - something about which, as we have seen, Taha is also very concerned. However, it is also an attack on American global politics and the support often given by the American government to autocratic regimes that provide the United States with primary resources such as oil.

During Operation Desert Storm, in the First Gulf War, in 1990/91, the track was appropriated by the invading American forces. It is said that 'Rock The Casbah' was the first track played on Armed Forces Radio when it was established in Saudi Arabia. In a review of Julian Temple's film about Strummer, Joe Strummer: The Future Is Unwritten, Ty Burr notes that: "When [Strummer] heard that American pilots had painted the words "Rock the Casbah" on a Desert Storm bomb, he wept' (2007: para. 2). Subsequently, in 2006, the song came in at number 20 on an admittedly rather odd listing of the '50 Greatest Conservative Rock Songs' (Miller 2006). ${ }^{8}$

From this perspective, Taha's revisioning of the song in Arabic reappropriates the song. In the first place the song becomes again a criticism of Islamic fundamentalism. Translating the lyrics into Arabic, utilising North African instruments alongside those traditional for rock music, and reworking the rhythm Arabizes the song and generates a very different set of reference points producing, as Bhabha calls it, a 'disruptive "anterior"'. The most important film about the Algerian War of Independence is The Battle of Algiers (La bataille d'Alger) directed by Gillo Pontecorvo in 1966, just four years after the end of the war. Made with the support of the new Algerian FLN government, the film's cast was mostly made up of amateurs while the film itself developed a reputation for its depiction of urban guerrilla warfare. The film is centred on the 
Algiers casbah which the FLN leadership occupies and in which the French military hunts them down. In his autobiography, Taha describes The Battle of Algiers as: 'Un ... film de guerre m'a bouleversé' [A war film that very much distressed me] and describes how the film 'reconte ... la repression dans la Casbah d'Alger' [tells the story of the repression in the Casbah of Algiers) (Taha and Lacout 2008: 51). Here we should remember Taha's story about the French torture and murder of his uncle during the War of Independence. Taha's Arabized version of 'Rock El Casbah' acts as a source of anamnesis reminding both the French and the Algerians of their shared colonial past and the bloody transgressions that they also share.

There is a twist in this story. As I have mentioned, the Clash were an important group for Taha. Abdel-Jaouad remarks that: 'One of Taha's biggest influences was the Clash's lead singer Joe Strummer' (2010: 130). Taha went to see the group when the Clash played a seven-night residency at the Théâtre Mogador in Paris in September 1981. More, he took with him a demo tape of tracks by Carte de Séjour which he managed to give to the group. As he tells it:

\footnotetext{
'They looked interested,' remembers Taha, 'but when they didn't get in touch, I thought nothing of it. Then, a few months later, I heard Rock the Casbah.'
}

He cackles mischievously. 'Maybe they did hear it after all.'

(Lewis 2007: para. 2)

Taha is on record with many versions of the story. So, perhaps there is another history for 'Rock The Casbah', one where the song's genesis lies not in the first place in Strummer's concern about oppression in Iran or in his reaction to something that the Clash's manager Bernie Rhodes had said (Salewicz: 310), but, rather, in now unknown tracks by Carte de Séjour. Perhaps here we have a narrative of unthinking colonial appropriation—or, at least, another tale of inspiration being drawn from the colonial experience. Perhaps this is a narrative about postcolonial power, about an influential Western rock group looking for ideas for their next album and utilising, maybe unwittingly, ideas from tracks by a young Beur group who, at that time, had no recording history. In this case, Taha is not so much reappropriating 'Rock The Casbah' from its rightwing, and military, appropriation, as taking back what was in some form originally his.

Strummer died in 2002, before Taha's revisioning. However, Mick Jones, the Clash's lead guitarist, has performed 'Rock El Casbah' with Taha a number of times since the track was 
released on Tékitoi. In April, 2007, for example, Jones joined Taha on stage at the Barbican in London when 'they crashed into a rousing version of Rock El Casbah, the Arabic treatment of the Clash's anthem that has become one of Taha's standards. It was a rousing end to a furious show' (Denselow 2007: para. 1). Taha has commented on the post-punk Clash that:

\footnotetext{
When you listen to 'Sandinista' or 'London Calling', there were many musical expressions that came from all over the world. There was the electronic spirit, the trance, the rock, all kinds of things. It was like an Arab grocery, where one can find all kinds of things to eat and drink.
}

(Bottenberg 2005: para. 18)

This seems to be how Taha sees Carte de Séjour's influence on the Clash. At the same time, Taha sees himself as a rebel in the same way that Strummer did. The difference being, and it is crucial, that Taha has a subaltern, colonial background. There is a sense in which the track now has no origin, or two, colonial and subaltern-or, better, simply postcolonial. 'Rock El Casbah' is a product of the postcolonial presence in France; and it is a track made for dancing.

In this essay I have argued that the hybrid quality which marks Taha's life, as it does that of all Beurs, is key to understanding the force of his music. I began with a discussion of an important early track by Carte de Séjour which sets out the importance of métissage. I have, though, particularly focused on the musical revisionings that pepper Taha's corpus. Indeed, Diwân (1998), and Diwân 2 (2006) mostly contain versions of chaabi and early rai songs. Certain revisionings, though, have more cultural power because of the status of the original tracks. It is these with which I have been most concerned. Carte de Séjour's version of 'Douce France' functioned to remind the French of the presence of a North African generation born and brought up in France and for whom France has to be home. Taha's version of 'Ya Rayah' speaks to his own generation, offering an anguished cry for a home denied them. An abyss remains between these two revisionings, the abyss between those who see themselves as French and those who tend to be excluded from Frenchness. In a crucial way, Taha's revisioning of 'Rock The Casbah' transcends this abyss, offering a new, postcolonial synthesis that brings together France and its Algerian colonial history. And, always through Taha's work, there is the 
dance; dancing not as a solution to racist divisions but as an alternative-dancing as an ecstatic activity that unifies people regardless of creed or skin colour. 


\section{References}

Abdel-Jaouad, Hédi (2010), 'Beur Hybrid Humour' in Graeme Dunphy and Rainer Emig Hybrid Humour: Comedy in Transcultural Perspective, Amsterdam and New York: Rodopi, pp. $113-137$.

Anon. (2012), “'Chaabi' (Algeria) from Wikipedia', http://en.wikipedia.org/wiki/Chaabi_ (Algeria). Accessed 16 December 2011.

Ashcroft, Bill (2001), Post-Colonial Transformation, London and New York: Routledge.

Bhabha, Homi K. (1994), The Location of Culture, London and New York: Routledge.

Bleich, Erik (2004), 'Anti-Racism without Races: Politics and Policy in a "Color-Blind" State', in Herrick Chapman and Laura Levine Fraker (eds), Race in France: Interdisciplinary Perspectives on the Politics of Difference, Oxford and New York: Berghahn, pp. 162188.

Bottenberg, Rupert (2005), 'Combat Rocker', Montreal Mirror, 24 February. http://colodez.spb.ru/kladovaya/rtpress/combat.html . Accessed 12 December 2011.

Bourdieu, Pierre and Wacquant, Loïc (2000), 'The Organic Ethnologist of Algerian Migration', Ethnography, 1: 2, pp. 173-182.

Burr, Ty (2007), “'Strummer” Illuminates the Man and the Music', Boston.com, 09 November, http://www.boston.com/ae/movies/articles/2007/11/09/strummer_illuminates_the_man_a nd_music/?page=2 . Accessed 14 December 2011.

Cooper, Frederick (2009), 'From Imperial Inclusion to Republican Exclusion? France's Ambiguous Postwar Trajectory', in Charles Tshimanga-Kashama, Didier Gondola, and Peter Bloom (eds), Frenchness and the African Diaspora: Identity and Uprising in Contemporary France, Bloomington: Indiana University Press, pp. 91-119.

Denselow, Robin (2007), 'Rachid Taha/Vieux Farka Touré', The Guardian, 09 April, http://www.guardian.co.uk/music/2007/apr/09/worldmusic .livereviews. Accessed 17 December 2011.

Erlewine, Stephen T. (2012) 'the Clash' at AllMusic, http://www.allmusic.com/artist/the-clashp3913. Accessed 23 December 2011. 
Evans, Martin and Phillips, John, (2008) Algeria: Anger of the Dispossessed, New Haven and London: Yale University Press.

Fanon, Frantz (1986), Black Skins White Masks, London: Pluto.

Guarisco, Donald A. (2012), 'Rock The Casbah' at AllMusic, http://www.allmusic.com/song/rock-the-casbah-t3310796 . Accessed 23 December 2011.

Hall, Rodney, Hargreaves, Alec, Marshall, Bill and Ridehalgh, Anna (1995), 'French in the World: From Imperialism to Diversity', in Jill Forbes and Michael Kelley (eds) French Cultural Studies: An Introduction, Oxford and New York: Oxford University Press, pp. $264-289$.

Jones, Christa (2009), 'Rock el Casbah!: Identité et espace urbain chez Rachid Taha', Expressions Maghrébines: Métropoles Maghrébines, 8: 2, pp. 111-129.

Lacout, Dominique and Rachid, Taha (2008), Rock la casbah, Paris: Flammarion.

Lewis, John (2007), 'Paris Calling', The Guardian, 30 March, http://www.guardian.co.uk/music/2007/mar/30/worldmusic . Accessed 18 December 2011.

Lloyd, Christopher (2003), 'Divided loyalties: singing in the Occupation' in Hugh Dauncey and Steve Cannon (eds), Popular Music in France from Chanson to Techno: Culture, Identity and Society, Aldershot: Ashgate, pp. 153-170.

Looseley, David (2003a), 'In from the margins: Chanson, pop and cultural legitimacy' in Hugh Dauncey and Steve Cannon (eds), Popular Music in France from Chanson to Techno: Culture, Identity and Society, Aldershot: Ashgate, pp. 27-40.

_ (2003b), Popular Music in Contemporary France: Authenticity, Politics, Debate, Oxford: Berg.

Marranci, Gabriele (2000a), 'A Complex Identity and its Musical Representation: Beurs and Raï Music in Paris: Some Aspects of Algerian Immigration in France', Journal of Musical Anthropology of the Mediterranean, 5, http://www.muspe.unibo.it/wwcat/period/ma/index/number5/marranci/marr_1.htm . Accessed 05 December 2011. 
(2000b), 'A Complex Identity and its Musical Representation: Beurs and Raï Music in

Paris: The Relationship Between Algerian Immigrants, Beurs, and Raï Music', Journal of Musical Anthropology of the Mediterranean, 5, http://www.muspe.unibo.it/wwcat/period/ma/index/number5/marranci/marr_3.htm . Accessed 05 December 2011.

Mbembe, Achille (2004), 'The Republic and Its Beast: On the Riots in the French Banlieues', in Charles Tshimanga-Kashama, Didier Gondola, and Peter Bloom (eds), Frenchness and the African Diaspora: Identity and Uprising in Contemporary France, Bloomington: Indiana University Press, pp. 47-54.

Meouak, Meouak and Aguadé, Jordi (1996), 'La Rhorhomanie et les Beurs: l'example de deux langues en contact', Estudios de dialectología norteafricana y andalusí (e.d.n.a), 1, pp. $157-166$.

Miller, John J. (2006), “'Rockin' the Right”: The 50 Greatest Conservative Rock Songs', National Review Online, 26 May, http://www.nationalreview.com/articles/217737/rockin-right/john-j-miller . Accessed 12 December 2011.

Morgan, Andy (2011), 'Cheikha Remitti-Grande Dame of Algeria's school of hard knocks!', http://www.andymorganwrites.com/cheikha-remitti-grand-dame-of-algerias-school-ofhard-knocks/ . Accessed 17 December 2012.

Nair, Parvati (2007), 'Migration, Transgression and Relocation in Spanish/Moroccan Rai', in Ian D. Biddle and Vanessa Knights (eds), Music, National Identity and the Politics of Location: Between the Global And the Local, Aldershot: Ashgate, pp. 65-80.

Nickson, Chris (2001), 'The Year of Desert Rose', Saudi Aramco World, December, www.saudiaramcoworld.com/issue/200106/the.year.of.desert.rose.htm. Accessed 22 December 2011.

O'Brien, Jon (2012), 'Rachid Taha: Biography', http://www.allmusic.com/artist/rachid-tahamn0000862583. Accessed December 2011.

Parkvall, Mikael (2005a), 'Forward to Alan D. Corré's A Glossary of Lingua Franca', https://pantherfile.uwm.edu/corre/www/franca/edition3/foreword.html . Accessed 16 December 2012. 
- (2005b), 'Introduction to Alan D. Corré's A Glossary of Lingua Franca', https://pantherfile.uwm.edu/corre/www/franca/edition3/lingua.3.html . Accessed 16 December 2012.

Sa'adah, Anne (2003), Contemporary France: A Democratic Education, Oxford: Rowman and Littlefield.

Salewicz, Chris (2008), Redemption Song: The Ballad of Joe Strummer, London: Faber \& Faber.

Schade-Poulsen, Marc (1999), Men and Popular Music in Algeria: The Social Significance of Rai, Austin: University of Texas Press.

Sherzer, Dina (1998), 'French Colonial and Post-Colonial Hybridity’, Journal of European Studies, 28: 1, pp. 103-120.

Silverstein, Paul A. (2002), “Why Are We Waiting To Start The Fire?”: French Gangsta Rap and the Critique of State Capitalism', in Alain-Philippe Durand (ed), Black, Blanc, Beur : Rap Music and Hip-Hop Culture in the Francophone World, Lanham: Scarecrow, pp. $45-67$.

Silverstein, Paul A. (2004), Algeria in France: Transpolitics, Race, and Nation, Bloomington: Indiana University Press.

Taha, Rachid et al (1987), 'Sleeve notes to Ramsa', [Carte de Sejour Album] [CD], Piranha.

Taha, Rachid (1998), Diwân, [CD], London: Island.

Taha, Rachid (2006), Diwân 2, [CD], London: Wrasse.

Virolle, Marie (2003), 'Representations and Female Roles in the Raï Song' in Tullia Magrini (ed), Music and Gender: Perspectives from the Mediterranean, Chicago: University of Chicago Press, pp. 215-232.

Young, Robert (1995), Colonial Desire: Hybridity in Theory, Culture and Race, Abingdon: Routledge. 
I would like to thank my research assistant Laura Glitsos for her work editing this article. The translations of quotations are hers and mine.

${ }^{1}$ I must thank Christa for emailing me a copy of her article when I was having trouble finding it. I strongly recommend it for its insights into Rachid Taha's music.

${ }^{2}$ This biographical material comes from the first two chapters of Taha's autobiography, Rock la Casbah.

3 An anthology drawn from these recordings was later released internationally under the title Ramsa in 1987.

4 This assertion is difficult to prove, not least because the listing of artists that have played the Palais des Sports on the not necessarily accurate Wikipedia at http://en.wikipedia.org/wiki/Palais_des_Sports_(Paris) only lists Téléphone playing there in 1979, that is, before Carte de Séjour were formed.

5 It is worth noting that Trenet is said to have given his approval to Carte de Séjour's version of 'Douce France'. See Taïeb, Eric (1998), Immigrés:l'effet générations. Rejet, assimilation, intégration d'hier et d'aujourd'hui, IvrySur-Seine: Editions de l'Atelier. p. 72.

${ }^{6}$ On this development see Schade-Poulsen, Marc (1999), Men and Popular Music in Algeria: The Social Significance of Rai, Austin: University of Texas Press, p. 35. Schade-Poulsen's book remains the most detailed discussion of rai available.

7 Steve Hillage, who had been in the English progressive rock group Gong, arranged the music. Hillage also produced all Taha's solo albums from Olé Olé to Diwãn 2 as well as producing Carte de Séjour's Rhorhomanie.

${ }^{8}$ The list also includes songs by The Who and The Rolling Stones among others. 